\title{
PRODUCTION PERFORMANCE OF GINGER: A STUDY AMONG INDIAN STATES
}

\author{
Manuranjan Gogoi \\ Assistant Professor (Contract), Department of Economics, Madhabdev University, \\ Narayanpur, Assam, India
}

\begin{abstract}
Ginger is one of the high value spices. It has the potentialities of marketing in the domestic as well as international level. In India, all the states of country have significant contribution to its total ginger production. The climate and the land composition for the cultivation of ginger are most favorable in this region. The paper aims to study the production performance of ginger in India and to explore the problems and prospects of ginger production.
\end{abstract}

Key words: Ginger, Production, Problems and Prospects, India.

Cite this Article: Manuranjan Gogo, Production Performance of Ginger: A Study among Indian States, International Journal of Management, 11(12), 2020, pp. 845850.

http://iaeme.com/Home/issue/IJM?Volume=11\&Issue=12

\section{INTRODUCTION}

India is one of the major producers of spices in the world. According to Bureau of Indian standards (BIS), there are 63 spices grown in India. Ginger is one of the important spices of them and playing an important role in production and export of the country. According to Food and Agriculture Organization of the United Nations (FAO, 2017-18), India is the second largest ginger producer in the world after china. The country produces around 22.89 percent of ginger of the world. Among all the states of India, Assam produces highest ginger. The state produces 14.97 percent of India's ginger production and covered 11.73 percent of land area under ginger cultivation. The state produces highest ginger among all the states of India and covers second highest land area under ginger cultivation after Karnataka. According to Ministry of Agriculture \& Farmers Welfare, Govt. of India the state produces around 167.39 thousand MT ginger in 2017-18. But the productivity/hectare is only 8.91 MT which is lower than Gujarat, Haryana, Kerala, Maharashtra, Nagaland, Uttar Pradesh, Uttarakhand and West Bengal. 


\section{REVIEW OF LITERATURE}

Yukurshi et. al (2011), studied technical efficiency of Ginger producers in Kaduna State, Nigeria to provide information for effective application and management of farm inputs and policy recommendations by using a Stochastic Production Frontier Function. The result of the study found mean efficiency is 62.09 percent which implies a significant potential for the farmers to sustainably increase output using the available inputs and also signifies a considerable inefficiency among the ginger farmers and thats why the study recommends to increase technical efficiency so as to improve ginger production.

Islam et. al (2012), made a study entitled "Economic Performance of Ginger Cultivation in Some Selected Locations of Bangladesh" with the objectives of studying technical efficiency of ginger growers especially in Nilphamari and Khagrachari Districts. The study reveals that ginger production was profitable and average benefit cost ratio was 2.17. The average level of technical efficiency among the sample farmers is 85 implying that given the existing technology and level of inputs, the output could be increased by 15 percent.

By using the Stochastic Frontier Production Model to examine the technical efficiency of ginger crop production in Jaba Local Government Area, Kaduna State in Nigeria, Solomon T. \& Korede M. (2013) found that there is scope for increasing the technical efficiency of ginger crops production by $0.68 \%$ with the existing technology. The study also attempted to explore the factors that determine the differential in efficiency index and found the farm size, planting material, fertilizer and hired labour statistically significant.

Vanrammawia, K. (2015) studied marketing efficiency of ginger in Mizoram on the basis of their institutional arrangements and reveals that the ginger market is characterized by market imperfections with high degree of market instability and lack of market integration in terms of price.

Sati \& Bala (2017) have made a comparative analysis of ginger cultivation methods in Kaduna State, Nigeria. They have categorized the methods of ginger cultivation into three categories viz. flatbed, mound or raised and ridges tillage to identify the best method that gives higher yield with minimum soil erosion and found the flatbed method is the best method which encourages growth of all the plants.

By applying Malmquist productivity index and Auto Regressive Distributed Lag Model to estimate the productivity of ginger and long run and short run determinants of ginger productivity respectively in Nigeria from 1961-2016,

Onwusiribe et. al (2017) found that throughout the study period, the ginger productivity has been increasing marginally. Auto Regressive Distributed Lag Model suggests that rainfall and temperature had a long run positive and negative impact respectively on ginger production. On the other hand, capital had both positive and negative impacts on the productivity of ginger in the long run and short run. Therefore the study recommended that the availability and accessibility of capital is very essential for increasing the production of ginger in Nigeria.

To examine the input use levels and economics of ginger cultivation, Mathew et. al (2018) have made a study in Wayanad district of Kerala and it indicated that cost of cultivation and gross returns were positively related with the size of the holding. All the farm incomes measures exhibited a positive relationship with the farm size.

\section{OBJECTIVES}

- To see production performance of ginger in India.

- To explore the problems and prospects of ginger cultivation. 


\section{DATA SOURCE AND RESEARCH METHODOLOGY}

The study will be based on secondary sources only. Data are collected from various sources like Agricultural and Processed Food Products Export Development Authority (APEDA), NABARD, NEDFi, Ministry of Agriculture and Farmers Welfare, Govt. of India, Spice Board of India, Ministry of Horticulture, Govt. Of India, Census of India, Statistical handbook of India, Food and Agriculture Organization (FAO) etc.

\section{ANALYSIS}

Ginger is one of the high value spices and has the potentialities of marketing in the domestic as well as international level. India is one of the dominant ginger producers of the world and the quality of its fresh ginger is very high. The following Figure 1 shows the top 10 ginger producer country of the world.

Table 1 Country wise ginger production, Land covered and productivity

\begin{tabular}{|c|c|c|c|}
\hline Country & Area (000 Ha) & Production (000 Tons) & $\begin{array}{c}\text { Productivity (tons/ } \\
\text { Ha) }\end{array}$ \\
\hline China & 36.10 & 396.60 & 10.99 \\
\hline India & 107.54 & 385.33 & 3.58 \\
\hline Nepal & 18.04 & 210.79 & 11.68 \\
\hline Thailand & 10.25 & 172.68 & 16.85 \\
\hline Nigeria & 52.33 & 162.22 & 3.10 \\
\hline Indonesia & 60.47 & 109.02 & 1.80 \\
\hline Bangladesh & 9.07 & 74.84 & 8.26 \\
\hline Philippines & 3.97 & 27.10 & 6.83 \\
\hline Republic of Korea & 2.09 & 24.97 & 5.82 \\
\hline Sri Lanka & 2.07 & 12.05 & 12.62 \\
\hline Other Countries & 8.51 & 107.39 & 5.42 \\
\hline Total & 310.43 & 1683.00 & \\
\hline
\end{tabular}

Source: FAO

Table 1 shows the land area of ginger cultivation, production of ginger and the productivity of ginger in different regions of the world. From the table it is found that, China is the largest producer of ginger of the world and produced around 396.60 tons of ginger. But the productivity of china is 10.99 tons/hectare. India is the second largest producer of ginger of the world after China. But, in India the land area of ginger cultivation is higher than china. So, the productivity of ginger in India is less than China and it is around 3.58 tons/ hectare only. On the basis of productivity Thailand is in highest position of the world and it is around 16.85 tons/ hectare. From the table it is also found that the countries Nepal, Nigeria, Indonesia, Bangladesh, Philippines, Republic of Korea, Sri Lanka etc. are playing a crucial role in the production of ginger.

In India, all the states of country have tremendous contribution to its total ginger production of the whole nation. Ginger farming has various contributions for employment generation as well as income generation for its farmers of the country. From many decades 
ginger production of the country playing a vital role of the country's economy. The following figure 1 shows the trend of ginger production of India.

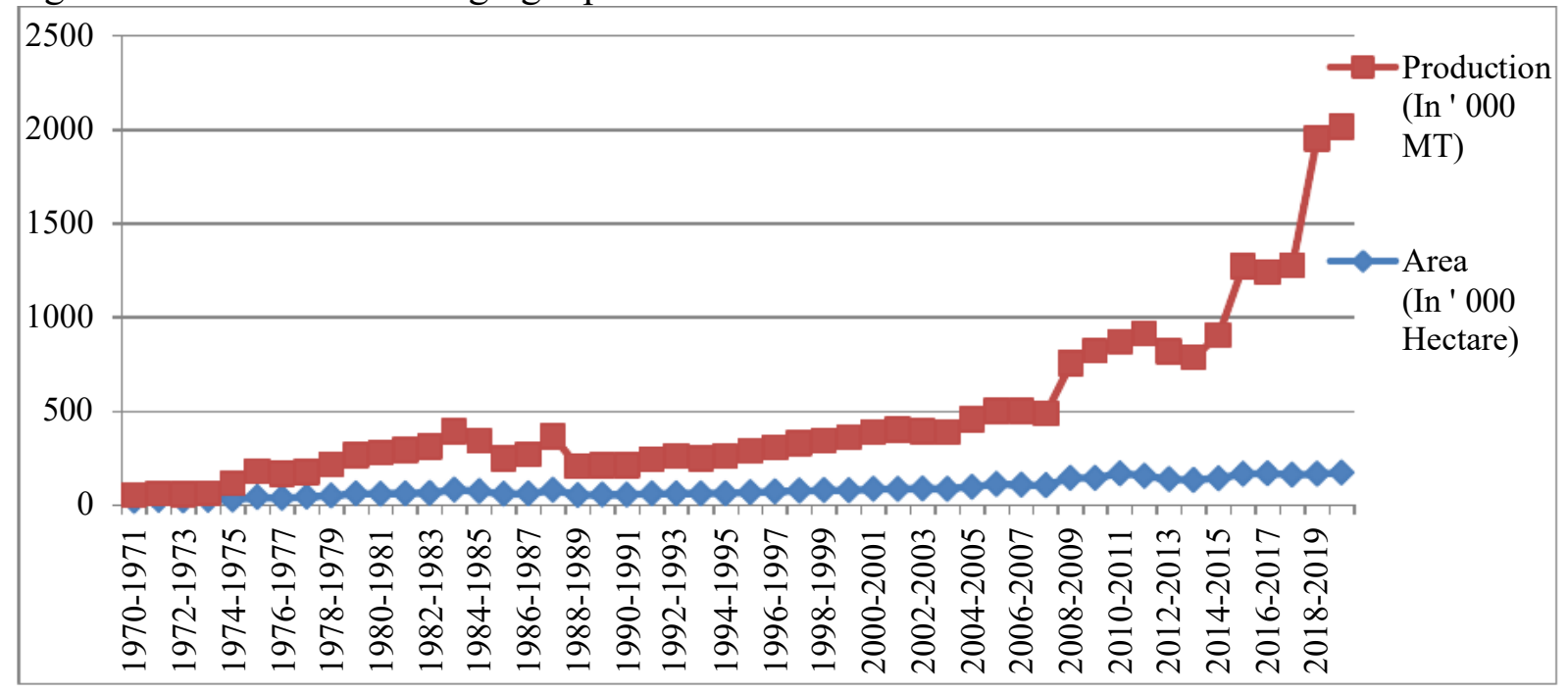

Figure 1 Trend of India's Ginger Production

Note: Data in terms of fresh ginger

Source: Spice Board, India \& Ministry of Agriculture and Farmers Welfare, Govt. of India. (ON2287) \& Past issues

From the figure 1, it is found that production of ginger growing faster than its land area. During these periods the productivity (In MT/Hectare) of ginger in the year 1970-71 it was $1.4,1980-81$ it was 3.7, 1990-91 it was 2.8, 2000-01 it was 3.6, 2010-11 it was 4.2 and 201920 it is around 10.7. This is resulted that productivity of ginger during the pre WTO regime is not more impressive but after the WTO regime the country doing better in each decades. The continuous increase in productivity of ginger after the WTO regime may be a cause of technological improvement or the use of HYV seeds. The following table 2 shows the state wise production and area of land covered by the ginger cultivation.

Table 2 Sate wise ginger production 2017-18 (Top 10 States)

\begin{tabular}{|c|c|c|}
\hline States & Production (000 Tonnes) & Share (\%) \\
\hline Assam & 167.39 & 17.53 \\
\hline Maharashtra & 140.60 & 14.72 \\
\hline West Bengal & 130.40 & 13.65 \\
\hline Gujarat & 108.25 & 11.33 \\
\hline Kerala & 86.27 & 9.03 \\
\hline Meghalaya & 66.20 & 6.93 \\
\hline Mizoram & 60.13 & 6.30 \\
\hline Karnataka & 58.39 & 6.11 \\
\hline Nagaland & 48.65 & 5.09 \\
\hline Uttarakhand & 19.07 & 2.00 \\
\hline Total & 885.35 & - \\
\hline
\end{tabular}

Source : National Horticulture Board (NHB) 
From table 2 it is found that, Assam is the largest ginger producer of the country and produces around 167.93 thousand tons ginger in the year 2017-18. The contribution from the state Assam to the total production of ginger of the country is 17.53 percent. After Assam, Maharashtra and West Bengal are the second and third largest ginger producer states of the country and constituted around $14.72 \& 13.65$ share to the total production of the country. On the other hand, the state Uttrakhand produces lowest among all the states of the country and constituted around 19.07 thousand tons production of ginger and the share to the country's production only 2 percent. Among all the states of North-east India, after Assam, the states Meghalaya and Mizoram second and third largest producer among all the states of NorthEastern region.

\section{PROSPECTS AND PROBLEMS OF GINGER CULTIVATION IN INDIA}

India is one of the market leaders of ginger after china. The climate and the land composition for the cultivation of ginger are most favorable in this region. In recent years there is a tremendous possibility of packaging food items. So, in that sense ginger have a possibility to capture the market. It also has a possibility of value addition by making it organic products and which will be more beneficial for the farmers. Adequate tanning and skill enhancement are also very necessary for the grower to make them efficient, and to compete with the global market. Role of government is also very necessary in terms of financial support to expand the production and market. Storage facility is another vital component for preservation of fresh ginger.

Major Problems faced by the farmers of the country-

- Due to the Shifting Cultivation in the hilly states of the country during a period of 3-4 years, regeneration of biomass in that land is insufficient so the production of agriculture is low.

- Most of the farmers of the country are marginal in nature, so the land holding is very small and they are not concern about the commercialization of ginger cultivation.

- High rainfall in the North-Eastern region of the country is one of the major problems of ginger cultivation.

- Low use of fertilizer and pesticide, productivity of ginger is low than compared with the other agricultural commodities.

\section{CONCLUSION}

This study was focused on production performance and prospects of ginger cultivation in India. From the literature it was found that there is a need of attention to study about the ginger farming of India. From the data given by government of India, there is a huge prospect of ginger cultivation in the region. But there is a technological gap, which leads to a major barrier to expose the grower of the region. So, there is a urgent need to enhance the technological improvement to increase the productivity. Market accessibility is also very necessary to compete with the global market.

\section{REFERENCES}

[1] Islam, Q. M. Shafiqul, Matin, M. A. and Hossain, S.(2012), "Economic performance of Ginger cultivation in some selected locations of Bangladesh". Bangladesh J. Agril., ISSN-0258-7122, 37(1): PP.109-120. 
[2] Mailumo, S.,Dawang, C and Agulu, K. O. (2014), "Increasing production efficiency of ginger for poverty alleviation in Kaduna State, Nigeria: A Stochastic Frontier Approach". International journal of development and sustainability, ISSN:2186-8662, Vol-3, No-7,PP1468-1476.

[3] Mathew, M., Vani, N. and Aparna, B. (2018), "Economics of production of ginger in Wayanad district of Kerala, India". Economic Affairs, ISSN:0424-2513, Vol. 63, No. 3, PP$627-632$

[4] Melati, Ilyas, S., Palupi, R. and Susila, A. D. (2016), "Growth, Yield and Quality of Ginger from Produced through Early Senescence". International Journal of Applied Science and Technology, ISSN: 2221-0997,Vol.6, No. 1

[5] Nandi,J.A. (2011),"Technical Efficiency of Ginger Production in Kaduna State, Nigeria: The Stochastic Frontier Approach". Journal of Vocational and Technical Education, ISSN:15966267, Vol. 6 No. 1

[6] Nmadu, J. N. and Marcus, P. L. (2011), "Efficiency of Ginger Production in Selected Local Government Areas of Kaduna State, Nigeria". International Journal of Food and Agricultural Economics, ISSN: 2147-8988, Vol. 1, No. 2, PP. 39-52

[7] National Horticulture Board (NHB), Annual report 2017-18.

[8] Rahman, H., Karuppaiyan, R., Kishore, K. and Denzongpa, R. (2009), "Traditional Practices of Ginger Cultivation in Northeast India". Indian Journal of Traditional Knowledge, Vol:8, No. 1

[9] Sati, S. A. and Bala, G. (2017), "A Comparative Analysis of Ginger Cultivation Methods in Kurmin - Jatau, District of Jaba Local Government Area, Kaduna State, Nigeria". Asian Journal of Soil Science and Plant Nutrition, 1(1), PP. 1-18

[10] Solomon,T.F. \& Korede, M. A. (2013), "An analysis of Technical Efficiency of Ginger Crop Production in Jaba Local Government Area, Kaduna State, Nigeria". Pelagia Research Library, ISSN:0976-8610, 4(5), PP. 85-90

[11] Spice Board, India \& Ministry of Agriculture and Farmers Welfare, Govt. of India. (ON2287) $\&$ Past issues.

[12] Vanrammawia, K. (2015), "Agricultural Marketing Efficiency in Mizoram". Social Change and Development, Vol. XII, No. 1

[13] Yukurshi, Evans N., Owolabi, J.O., \& Nandi James A.(2011), "Technical efficiency of ginger production I kaduna state, Nigeria: The stochastic frontier Approach", Journal of Vocational and Technical Education, Vol-6, No-1, pp.75-80.

[14] http://apeda.in/agriexchange/Market\%20Profile/one/GINGER.aspx

[15] http://www.fao.org/home/en/ 